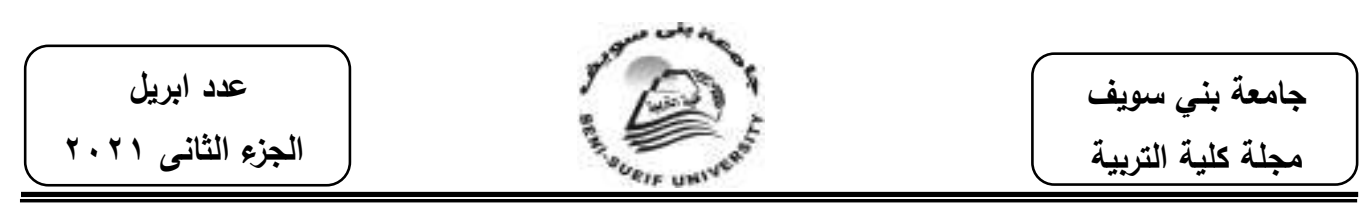

\title{
Using Project Based Learning (PBL) Program \\ Integrated with Information Technology (IT) on Developing Secondary Stage Students' \\ Speaking Skills. By: Manar Abd Allah Aly
}

\author{
Dr. Hayat Refaey Ali \\ Professor of Curriculum\& \\ Methods of TEFL \\ Faculty of Education, \\ Minia University
}

\author{
Dr. Mukhtar Abd El Fattah Abd El \\ Maksoud \\ Assistant Professor of Curriculum\& \\ Methods of TEFL \\ Faculty of Education, \\ Beni Suef University
}

\begin{abstract}
The aim of this study was to investigate the effect of Project Based Learning Program Integrated with Information Technology in developing Speaking skills of first year secondary school students. The Participants were sixty students. They were randomly assigned to a treatment group and a control group (30 students each). The instruments of the study included a checklist of Speaking sub- skills, a test on Speaking skills. The treatment group was taught using Project Based Learning Program while the control group was taught following the plan of the Ministry of Education in Egypt. The participants were pre - and - post tested. The program was administered in the first term of the academic year 2020/2021. Results revealed that Project Based Learning Program had positive results. Recommendations and suggestions for further research were presented.

Key words: project based learning, Information Technology and speaking
\end{abstract}


كان الهدف من هذه الدارسة هو معرفة تأثنر برنامج في التعلم القائم على المشروعات بالتكامل مع تكنولوجيا المعلومات ، في تتمية مهارات التحدث لدى طلاب الصف الأول الثانوي. كان المشاركون ستون طالبا نم تقسيميهم بشكل عشوائي إلى مجموعة تجريبية ومجموعةً ضابطة (·طالب لكل منهما). تضمنت أدوات الدراسة: اختبار التحدث. تم تدريس المجموعة التجريبية باستخدام برنامج في التعلم القائم على المشروعات بينما تم تدريس المجموعة الضابطة وفق لخطة وزارة التربية والتعليم في مصر • تم اختبار المشاركين

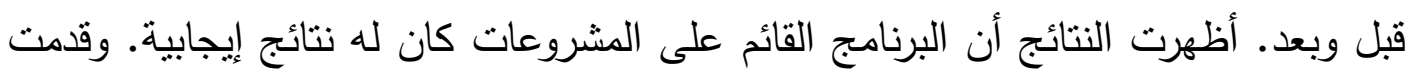
اقتراحات لمزيد من البحث. كلمات رئيسية: التعلم القائم على المشروعات ،تكنولوجيا المعلومات و التحدث. 


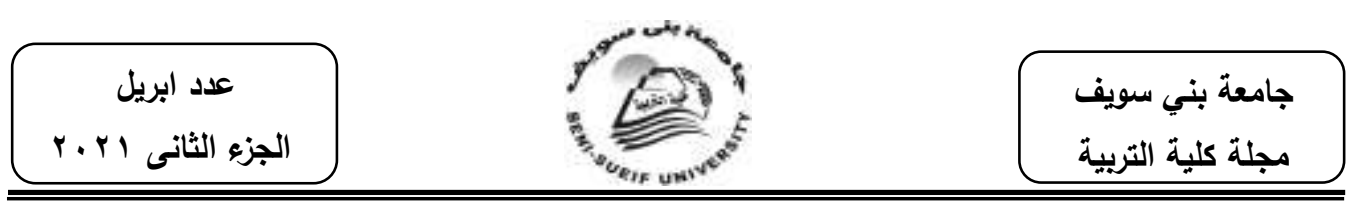

\section{Introduction}

One of the most critical problems in teaching and learning English is students' lack of adequate language skills background to enable them to carry out tasks required in studying English. One can't build a house without a strong foundation. Similarly, she will not become a well-rounded speaker of language without building upon the four foundations of language learning. Effective communication is a two-way activity involving both a sender and a receiver of a message. The listener or reader, has as much responsibility in understanding the message as the speaker or writer has in presenting it. For effective communication to occur, people need not only to speak or write but also to understand how others have perceived their messages if they are to respond in ways that address the concerns and questions of their audience.

According to Bueno, Madrid, and Mclaren (2006), "Speaking is one of the most difficult skills language learners have to face. Speaking is considered the most important of the four language skills of English. Brown and Yuke (1983) say, "Speaking is the skill that the students will be judged upon most in real life situations". Speaking skills are the most important skills for ELLs as they are very useful for them in exhibiting their communication skills for various purposes. Hence, the teachers have to take a special interest in improving the speaking skills of the ELLS.

To deal with this challenge, language teachers need to employ an appropriate English teaching and learning method that should encourage students to use language with an emphasis on communicative purposes in real world settings. Project-based learning (PBL) seems to match this English teaching and learning need. Projectbased learning has been investigated in a great number of studies on the global scale over the last decade. Project-based learning is a learning method which focuses on the learner. Project-based learning is a key strategy for creating independent thinkers and learners. (Valls, 2016). It is proved that knowledge gained through learner's own effort and thinking is likely to be stored in a long-term memory. However, 'readymade' pieces of information are usually forgotten very soon. 


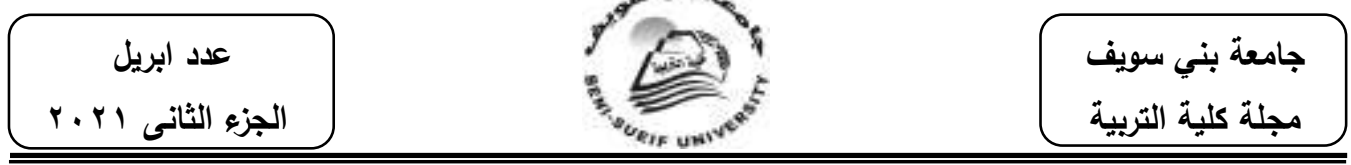

Hutchinson suggests that languages are learnt most effectively when we use them to solve problems. Problems make us think and we learn by thinking." (Hutchinson, 1999). There is a strong evidence that projects have the power to stimulate students to gather, compare, sort out and evaluate facts.

The ideology of PBL lies in "learning by doing", which means that learners acquire knowledge after having experienced or done something new (Kotti, 2008).Coufalová (2006) enforced the motto "learning by doing" and laid the four main principles that PBL (a) comes from the needs and interests of students; it enables them to fulfill their needs to gain new experiences and be responsible for their work; (b) comes from a concrete and actual situation thus it is not restricted by school premises but even parents and others from student surroundings can be involved; (C) is interdisciplinary; (d) is above all, an enterprise of a student; (e) the final product of PBL brings a concrete product and the process and result should be recorded; (f) is usually carried out in groups; (g) connects school with its neighborhood since it supports school integration into broader society and actual life.

Many studies referred that by using project-based learning, writing ability could be enhanced. Di Yang (2016) revealed that PBL had positive effects on non-English major students' speaking ability and students' opinions. Besides, improving students speaking abilities, it was reported that PBL could improve the listening and writing skill also.

Project Based Learning provides an authentic environment in which teachers can help students increase their cooperative-learning skills. It enhances collaboration and reflection, and allows competing solutions and diversity of outcome (Reeves, et. al, 2002).Motivation is one of the key features of PBL and one of its most important benefits. In essence, it says that if students are motivated and cognitively engaged, they will learn more and remember better.

An IT-assisted PBL lesson has multiple goals for students. Typically, these are Developing expertise, Improving research skills, Improving higher-order thinking skills, Participating in a project, Learning to use 


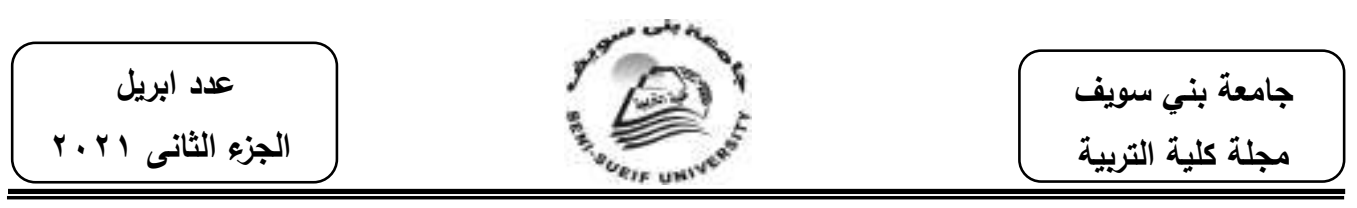

IT, conducting self-assessment and peer assessment, Developing a portfolio, Engaging in a project, Being a part of a community of scholars and working on important ideas.

\section{Context of the problem}

The researcher observed that first graders of Elsalam Secondary school have problems in acquiring the Speaking skills. She observed this problem through her teaching. To verify the problem, The researcher had conducted an interview with the English teachers at same school to ask them about students' level on speaking skills, the results showed that:

Table(1) students' level on speaking skills

\begin{tabular}{|c|c|}
\hline $\mathbf{N}$ & $\begin{array}{c}\text { Degree of weakness on } \\
\text { Speaking skill }\end{array}$ \\
\hline $\mathbf{1}$ & $\mathbf{6 0 \%}$ \\
\hline 2 & $\mathbf{6 8 \%}$ \\
\hline 3 & $\mathbf{6 3 \%}$ \\
\hline 4 & $\mathbf{6 2 \%}$ \\
\hline 5 & $\mathbf{6 5 \%}$ \\
\hline 6 & $\mathbf{6 8 \%}$ \\
\hline
\end{tabular}

The researcher found a consensus from the teachers that the majority of students faced problems in speaking skills.

\section{The Problem:}

The problem is that first year secondary school students in Minia governorate had problems in their communicative speaking skills. The present study tried to investigate using a program based on Project Based Learning (BPL) to solve these problems and to determine the effectiveness

of this

program.

\section{Questions:}

The present question attempted to provide an answer to the following question:

How effective would a program based on Project Based learning be on developing First Year Secondary School Students' Speaking Skills?

\section{Hypotheses of the Research:}

The following hypotheses were tested: 
- There would be a statistically significant difference (favoring the experimental group) between means of scores obtained by the

\section{Significance}

experimental and the control groups on the post-Speaking test.

The present study would develop Speaking skills of first secondary graders of Elsalam Secondary school. The present study would provide teachers with motivated and popular techniques for developing speaking skills of their students. The program of the present study would help teachers adopt new roles such as a facilitator and a guider.

\section{Limitations}

The study was limited to:

First year, at Elsalam secondary School students, Minia Governorate. (Participants are only females.)

Units of the first term of first year secondary school content were taught using a program based on of Project Based learning

\section{Material and methods:}

A pre-post quasi experimental design was used in the present study. The treatment and the non-treatment groups would be exposed to pre-post means of collecting data (A test in speaking\& writing skills). The treatment group would be taught using a program based on Project based learning program while the non - treatment group would be taught using the conventional methods followed when teaching EFL to first secondary graders .

\section{Variables:}

- Independent variable: A program based on Project based learning.

- Dependent variable:

Acquisition of Speaking skills

\section{- Control Variables:}

To ensure equivalence among the members of the two groups, the following variables were controlled: a. Performance on the pre - test of Speaking skills. - English proficiency level - Gender - Age

\section{Tools of the study}

To achieve the objectives of the present study the researcher prepared the following tools:- 
عدد ابريل

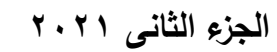

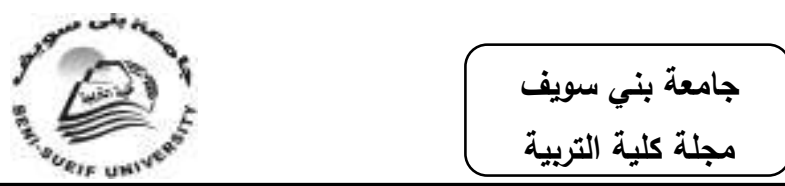

1. A checklist of sub skills of Speaking.

A. Objectives:

Identifying the sub skills of Speaking.

B. Construction:

The checklist consists of Speaking skills that related to eight units. Consulting a number of TEFL experts to identify the sub skills of the Speaking skills that appropriate for first secondary school students. Their suggestions were taken into consideration. These suggestions were reduce the number of items.

\section{A test in Speaking skills}

\section{A. Objectives:}

- Accuracy with Words \& Pronunciation

- Students practice using words, structures and pronunciation accurately

\section{- Using Functions}

- Students use specific phrases for purposes like giving advice, apologizing, etc

- Fluency

- Students practice speaking with a logical flow without planning or rehearsing.

The types of questions in Speaking Test are (open-ended questions) with items based on the learning outcomes and the objectives of the program .

\section{A. Construction :}

- The test was designed on the basis of a table of specifications.

- A panel of TEFL and EFL staff members evaluated the test in the light of the table of specifications and recommended editing of some items.

- The test in its final form consisted of 7 items covering the eight units.

\section{B. Item Type:}

The test item types included the essay and productive types (open-ended). 
عدد ابريل

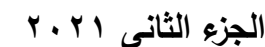

\section{Scoring:}

The score is simply the total number of correctly marked answers. Points given for each test item vary according response required from the participants; this is explained in the table of specifications. The total Score of this test is (20). Two raters of nearly the same qualifications participated in scoring the test items. The two scores of the two raters were calculated and the average was taken. Raters used a Speaking rubric to score the Speaking test. Correlation (0.76) between the two raters is high. It is significant at 0.01 level.

Table (2)

\section{Correlation Coefficient of the Scores of the Two Raters in the Speaking Test}

\begin{tabular}{|c|c|c|c|c|c|c|}
\hline \multirow[t]{2}{*}{ Variables } & \multicolumn{2}{|c|}{ First Rater } & \multicolumn{2}{|c|}{ Second Rater } & \multirow{2}{*}{$\begin{array}{c}\text { r- } \\
\text { value }\end{array}$} & \multirow[t]{2}{*}{ P-value } \\
\hline & Mean & $\mathrm{SD}$ & Mean & SD & & \\
\hline $\begin{array}{l}\text { Accurately \& } \\
\text { pronunciation }\end{array}$ & 1.43 & 0.57 & 1.57 & 0.57 & $\begin{array}{c}0.81 * \\
*\end{array}$ & 0.000 \\
\hline Fluency & 1.97 & 0.61 & 2.00 & 0.64 & $\begin{array}{c}0.87 * \\
*\end{array}$ & 0.000 \\
\hline Using Functions & 2.53 & 0.68 & 2.50 & 0.68 & $\begin{array}{c}0.82 * \\
*\end{array}$ & 0.000 \\
\hline Total & 5.93 & 1.01 & 6.07 & 0.94 & $\begin{array}{c}0.76^{*} \\
*\end{array}$ & 0.000 \\
\hline
\end{tabular}

\section{The Speaking Rubric:}

A Speaking rubric helps define essay requirements. The Speaking rubric is a tool a teacher can use to grade a student's Speaking in an objective manner. The rubric enables the teacher to see exactly what should be included in the Speaking. A Speaking rubric is also useful for students to know exactly what is required in their Speaking, enabling them to earn the best grade they can in an objective manner.

\section{E. Instructions:}

Instructions of the test are written in English in an easily and simple way to avoid any ambiguity. 


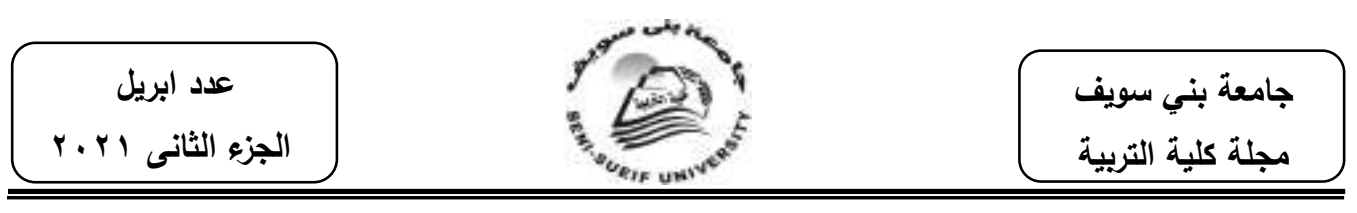

\section{F. Duration:}

Sixty minutes were assigned for answering the Speaking test. The researcher calculated the time between each student in the group. The average was taken.

\section{Test Validity:}

A pilot study was conducted about 15 days before administrating the program to estimate the validity and the reliability of the test.

\section{Face validity:}

The researcher distributed the test to five of a panel of TEFL and EFL experts to judge the linguistic stating of the items, suitability of the items to the participants and to the objectives. Their suggestions were taken into consideration. These suggestions were represented in the shortening of the number of items as it was too long, replacing some words in some questions, writing instructions of the test in the first page and numbering the items. The researcher arranged scores of the speaking's sub-skills (30students) exponentially to determine the highest quarters $(27 \%)$ and the lowest quarters (27\%). Then t-value was computed between the two quarters. The following table shows the results:

Table (3)

\section{t- value of the Highest and the Lowest Quarters in the Speaking Test}

\begin{tabular}{|c|c|c|c|c|c|c|}
\hline \hline \multirow{2}{*}{ Variables } & \multicolumn{2}{|c|}{ Low group } & \multicolumn{2}{c|}{ High group } & \multirow{2}{*}{ t-value } & $\begin{array}{c}\text { P- } \\
\text { value }\end{array}$ \\
\cline { 2 - 5 } & Mean & SD & Mean & SD & & 0.000 \\
\hline \hline $\begin{array}{c}\text { Accurately \& } \\
\text { pronunciation }\end{array}$ & 1.00 & 0.02 & 2.13 & 0.35 & $9.00 * *$ & 0.000 \\
\hline Fluency & 1.25 & 0.46 & 2.63 & 0.35 & $6.68 * *$ & 0.000 \\
\hline Using Functions & 2.00 & 0.01 & 3.38 & 0.52 & $7.51 * *$ & 0.000 \\
\hline Total & 4.88 & 0.64 & 7.06 & 0.18 & $9.31 * *$ & 0.000 \\
\hline \hline
\end{tabular}

* Significant at 0.05

** Significant at 0.01

The above table shows that there was significant difference between the high group and the low group in the Speaking Test (Favoring the high group). This assures the validity of the test.

\section{Test Reliability:}

The researcher used test - re-test method to calculate the reliability of the test. The researcher conducted the test on (30 students) and then 
عدد ابريل

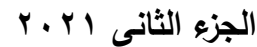

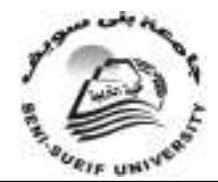

جامعة بني سويف

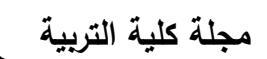

reconducted it after 2 weeks. The correlation coefficient between the first implementation of the test and the second one (re-test) is shown in the following table: Table $(\varepsilon)$ reveals that the correlation coefficient of the total mark reached (0.77). This is statistically significant and proves the reliability of the test. Aiken (1994), as cited in Latif (2012), stated that the test should have a reliability coefficient ranging from $(0.70)$ and preferably closer to $(0.90)$

Table ( $\varepsilon)$

\section{The Correlation Coefficient Between the Test and Re-Test of the Speaking Test}

\begin{tabular}{|c|c|c|c|c|c|c|}
\hline \multirow[b]{2}{*}{ Variables } & \multicolumn{2}{|c|}{ Test } & \multicolumn{2}{|c|}{ Re-Test } & \multirow{2}{*}{$\begin{array}{c}\text { r-value } \\
\text { Pearson } \\
\text { Correlatio } \\
\mathbf{n} \\
\end{array}$} & \multirow[b]{2}{*}{ P-value } \\
\hline & Mean & $\mathrm{SD}$ & Mean & SD & & \\
\hline $\begin{array}{l}\text { Accurately \& } \\
\text { pronunciation }\end{array}$ & 1.43 & 0.57 & 1.47 & 0.57 & $0.84 * *$ & 0.000 \\
\hline Fluency & 1.97 & 0.61 & 2.00 & 0.64 & $0.78 * *$ & 0.000 \\
\hline Using Functions & 2.53 & 0.68 & 2.50 & 0.63 & $0.80 * *$ & 0.000 \\
\hline Total & 5.93 & 1.01 & 5.97 & 0.96 & $0.77 * *$ & 0.000 \\
\hline
\end{tabular}

** Correlation is significant at the 0.01 level (2-tailed).

\section{Item Analysis:}

The researcher conducted the Speaking Test to identify the suitability of the test to the students. Thirty first year secondary school students were chosen randomly to answer the test. Item analysis was done after scoring the test to identify suitability of the items to the students and to provide information concerning the following points:

1- Index of difficulty.

2- Index of discrimination . 


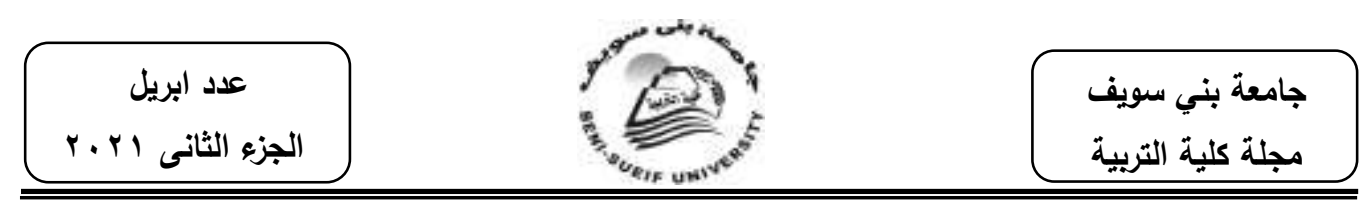

Table (5)

Difficulty Index and Discrimination Power of the Speaking Test of the Pilot Study

\begin{tabular}{|c|c|c|c|}
\hline \hline Number of Question & 1 & 2 & 3 \\
\hline \hline Simplicity index & 0.31 & 0.32 & 0.37 \\
\hline Difficulty index & 0.69 & 0.68 & 0.63 \\
\hline Discrimination Power & 0.21 & 0.22 & 0.23 \\
\hline \hline
\end{tabular}

Table ( 5 ) shows that :

1- Difficulty indices ranged from (0.63) to (0.69). These percentages show that the Speaking Test includes various questions that involve easy and difficult questions to suit the different levels of the participants.

2- The Speaking test had a positive discriminating power: The discrimination indices ranged from $(0.21)$ to $(0.23)$.

\section{Findings: Hypothesis 1}

Hypothesis (1) predicted that the treatment group would surpass the non - treatment group at the (.01) level on the post test of speaking skills. Table ( 7 ) shows the data obtained to verify this hypothesis.

Table ( $~()$

\section{t-Test Results of the experimental and the control groups on the post testing of Speaking}

\begin{tabular}{|c|c|c|c|c|c|c|}
\hline \hline \multirow{2}{*}{ Variables } & \multicolumn{2}{|c|}{ Experimental } & \multicolumn{2}{|c|}{ Control } & \multirow{2}{*}{ t-value } & \multirow{2}{*}{ P-value } \\
\cline { 2 - 6 } & Mean & SD & Mean & SD & & \\
\hline \hline $\begin{array}{c}\text { Accurately \& } \\
\text { pronunciation }\end{array}$ & 4.32 & 1.18 & 2.65 & 0.55 & $7.02 * *$ & 0.000 \\
\hline Fluency & 5.64 & 0.81 & 3.43 & 0.38 & $13.60 * *$ & 0.000 \\
\hline $\begin{array}{c}\text { Using } \\
\text { Functions }\end{array}$ & 6.26 & 0.54 & 3.18 & 0.40 & $25.11 * *$ & 0.000 \\
\hline Total & 16.88 & 3.47 & 9.26 & 0.66 & $11.84 * *$ & 0.000 \\
\hline \hline
\end{tabular}

* Significant at 0.05

$* *$ Significant at 0.01 
Based on the data in the above table, the t-value (11.84) obtained is significant at the (0.01) level. Thus, hypothesis (1) is accepted.

\section{Discussion}

The present study set out to determine the effect of a program based on Project Based Learning program (PBLP) integrated with Information Technology (PBLP\&IT) on the acquisition of speaking skills. The results showed that students learned speaking easily through this program. Table (6) shows that the treatment group outperformed the non-treatment group. Results revealed in table (6) confirmed hypothesis 1 . Participants of the treatment group (who were taught by the program) surpassed their counterparts in the non - treatment group (who were taught by the conventional methods), in speaking test.

It can be concluded that there is a significant effect of PBL on participants' speaking test. In other words, the implementation of PBL in EFL classes significantly affect students' productive skills in English. This is in line with a similar research conducted by Yang and Puakpong (2016) who involved eighty students in Kaili University. They found that there was a positive effect of PBL on non-English major Chinese students' speaking ability. Another positive outcomes of students' opinion towards PBL implementation in the classroom was also revealed.

\section{Table( 7 ) \\ The experimental Speaking of post \& pre Test}

\begin{tabular}{|c|c|c|c|c|c|c|c|}
\hline \hline \multirow{2}{*}{ Variables } & \multicolumn{2}{|c|}{ Pre Testing } & \multicolumn{2}{c|}{ Post Testing } & \multirow{2}{*}{ t-value } & \multirow{2}{*}{ P-value } & \multirow{2}{*}{$\boldsymbol{\eta} \mathbf{2}$} \\
\cline { 2 - 8 } & Mean & SD & Mean & SD & & \\
\hline \hline $\begin{array}{c}\text { Accurately \& } \\
\text { pronunciation }\end{array}$ & 1.41 & 0.32 & 4.32 & 1.18 & $15.39 * *$ & 0.000 & 0.89 \\
\hline Fluency & 1.99 & 0.37 & 5.64 & 0.81 & $26.96 * *$ & 0.000 & 0.96 \\
\hline Using Functions & 2.29 & 0.44 & 6.26 & 0.54 & $42.12^{* *}$ & 0.000 & 0.98 \\
\hline Total & 5.69 & 0.86 & 16.88 & 3.47 & $17.35 * *$ & 0.000 & 0.91 \\
\hline \hline
\end{tabular}

* Significant at 0.05

** Significant at 0.01 


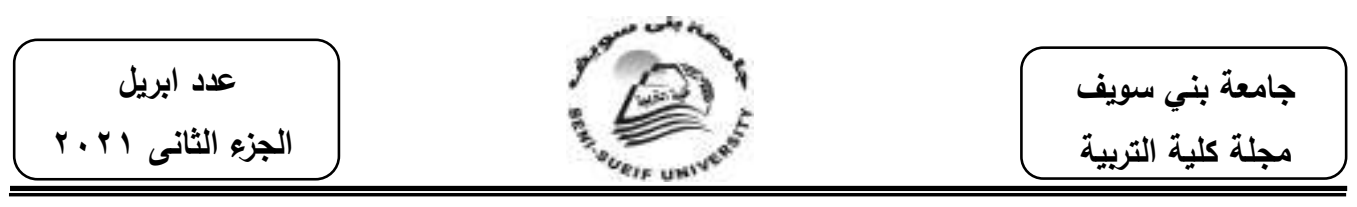

The above table ( 7 )shows that the $\mathrm{t}-$ value ranged from (15.39) to (42.12). Also, the $\eta 2$ - value ranged from (0.89) to (0.98). This refers to the effect of the Project Based Learning Program (PBLP) in developing first secondary school students' speaking.

The findings of the present study coincide with the literature reviewed. The results coincide with the results of those studies investigating the effects of using (PBLP) on developing speaking skills. There is a consensus between the results of the present study and those of other studies investigating the positive effects of (PBLP) on speaking skills: The researcher noted that the program of project based learning integrated with information technology motivated students to use language and participate. Rayan and Deci (2000) stated that where there is motivation, it leads to productivity. Using the program of the present study had a positive effect on increasing motivation of students of the treatment group. It leads to the development of acquiring speaking skills. It was further noted that confidence increased among pupils of the treatment group. They were provided with skills that enabled them to depend on themselves in producing language.

\section{Conclusion}

The discussion above demonstrated that using the PBLP could be effective in developing speaking skills. Suggestions for further

\section{research:}

- A replication of the present study to be implemented on a wide number of students and different grades.

- The effect of a Project Based Learning Program on developing productive language skills.

- The effect of a Project Based Learning Program on developing independent learning at the secondary stage.

- The effect of Project Based Learning Program on reducing anxiety and increasing confidence.

- Investigating the effect of using Project Based Learning Program on developing students' communication skills. 


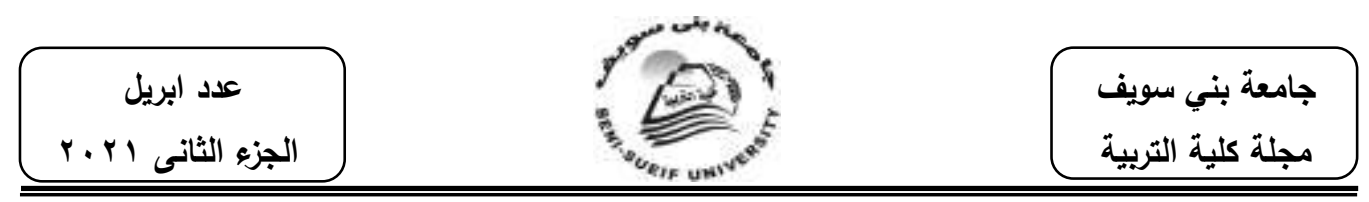

\section{References:}

Brown, G. and G. Yule. (1983). Teaching the Spoken Language. Cambridge:

Cambridge

University Press.

Brown, G. and G. Yule. (1983). Teaching the Spoken Language. Cambridge: Cambridge University Press.

Bueno, A, D. Madrid and N. McLaren, (eds). (2006) TEFL in Secondary Education.Granada: Editorial Universidad de Granada

Coufalová, J. (2006). Projektovévyučování. Praha: Nakladatelství Fortuna.

Di Yang. (2017). Effects Of Project -Based Learning On Speaking Abilities Of Non-English Major Chinese Students: University of Technology, Thailand

Hutchinson, T. (1996). Hotline: Intermediate. Workbook. Oxford: Oxford University Press.

Kotti, D. (2008). Experiential learning from theory to practice. Adult Education, 13,35-41.. (in Greek)

Reeves, T.C., Herrington, J., \& Oliver, R. (2002). Authentic activities And online learning. In A. Goody, J. Herrington \& M. Northcote (Eds.), Quality conversations: Research and Development in Higher Education, Volume 25 (562-567). Jamison, ACT: HERDSA.

Ryan, R. \& Deci, E. (2000). "Self-Determination Theory and the Facilitation of Intrinsic Motivation, Social Development, and WellBeing" The American Psychological Association, Inc Vol.55; No. 1; Pp. 68-78.

Valls, B. (2016). "Analysis of Project Based Learning in a Digital Environment at a Networked High School," J. Educ.Teach.

Trainers, vol. 7, no. 1, 27-49, 2016.

Yang, D. \& Puakpong, N. (2016). Effects of project-based learning on speaking abilities of Non-English major Chinese students.

Proceedings of the Seventh CLS International Conference CLaSIC 2016.

https://www.fas.nus.edu.sg/cls/CLaSIC/clasic2016/PROCEEDINGS/yang_di.pdf (accessed 9/10/2016). 